\title{
Influence of ascorbic acid supplementation on copper metabolism in rats
}

\author{
BY GERRIT J. VAN DEN BERG* \\ Interfaculty Reactor Institute, Delft University of Technology, Mekelweg 15, $2629 \mathrm{JB}$ Delft, \\ The Netherlands
}

AND ANTON C. BEYNEN

Department of Laboratory Animal Science, State University, PO Box 80.166, 3508 TD Utrecht and Department of Human Nutrition, Agricultural University, PO Box 8129, $146700 \mathrm{EV}$ Wageningen, The Netherlands

(Received 2 April 1991-Accepted 12 November 1991)

\begin{abstract}
An attempt was made to unravel further the mechanism by which high dietary concentrations of ascorbic acid influence copper metabolism. The addition of ascorbic acid to the diet of rats caused about a twofold increase in plasma ascorbate concentrations and reduced group mean plasma and tissue concentrations of $\mathrm{Cu}$. The effect of $10 \mathrm{~g}$ ascorbic acid/kg diet was greater than that of $1 \mathrm{~g} / \mathrm{kg}$. Ascorbic acid feeding reduced blood haemoglobin concentrations and packed cell volume values. Dietary ascorbic acid caused a significant decrease in apparent $\mathrm{Cu}$ absorption from the intestine. Ascorbate, intravenously administered together with ${ }^{64} \mathrm{Cu}$, caused an increase in ${ }^{64} \mathrm{Cu}$ in the liver. Ascorbate, at concentrations occurring in plasma after ascorbic acid feeding, promoted the uptake of ${ }^{64} \mathrm{Cu}$ by isolated hepatocytes. Thus, ascorbate stimulated the efficiency of hepatic uptake of $\mathrm{Cu}$. Ascorbate, intravenously administered together with ${ }^{64} \mathrm{Cu}$, stimulated accumulation of ${ }^{64} \mathrm{Cu}$ in bile of rats with a bile duct cannula. In rats fed on ascorbic acid, intravenously administered ${ }^{64} \mathrm{Cu}$ was recovered in bile at increased rates. Dietary ascorbic acid enhanced the recovery of intraperitoneally administered ${ }^{64} \mathrm{Cu}$ in faeces. The ascorbateinduced stimulation of biliary ${ }^{64} \mathrm{Cu}$ excretion may reflect an increased hepatic uptake of ${ }^{64} \mathrm{Cu}$ and be caused by an increased specific activity of $\mathrm{Cu}$ in liver pools. It is suggested that dietary ascorbic acid reduces tissue $\mathrm{Cu}$ concentrations primarily by interfering with intestinal $\mathrm{Cu}$ absorption. Ascorbate increases the efficiency of hepatic uptake of $\mathrm{Cu}$, but this effect may not be causatively related with the reduced tissue $\mathrm{Cu}$ concentrations after ascorbic acid feeding.
\end{abstract}

Tissue copper: Vitamin C: Copper metabolism: Anaemia : Rat

In laboratory animals, high intakes of ascorbic acid cause reduced plasma and liver concentrations of copper and decreased plasma activities of ceruloplasmin $(E C$ 1.16.3.1) (Hunt et al. 1970; Milne \& Omaye, 1980; Smith \& Bidlack, 1980; Milne et al. 1981; Johnson \& Murphy, 1988). In addition, rats fed on large amounts of ascorbic acid develop anaemia, which may be the result of ascorbate-induced $\mathrm{Cu}$ deficiency (Johnson \& Murphy, 1988). In humans, ascorbic acid supplementation may induce decreased $\mathrm{Cu}$ concentrations and ceruloplasmin activities in serum (Finley \& Cerklewski, 1983; Jacob et al. 1987; Milne et al. 1988).

In rats fed on ascorbic acid, whole-body retention of orally administered ${ }^{64} \mathrm{Cu}$ was depressed (Van Campen \& Gross, 1968) and the apparent efficiency of $\mathrm{Cu}$ absorption reduced (Johnson \& Murphy, 1988). The disappearance of ${ }^{64} \mathrm{Cu}$ from ligated intestinal segments was depressed by the addition of ascorbate to the lumen (Van Campen \& Gross,

$$
\text { * For reprints. }
$$


1968). Simultaneous oral administration of ${ }^{64} \mathrm{Cu}$ and ascorbate increased the recovery of ${ }^{64} \mathrm{Cu}$ in faeces within $1 \mathrm{~d}$ when compared with the administration of ${ }^{64} \mathrm{Cu}$ alone (Van den Berg et al. 1990). Thus, it is plausible that ascorbate impairs Cu absorption.

Post-absorptively, ascorbate may also influence $\mathrm{Cu}$ metabolism. After intraperitoneal administration of ${ }^{64} \mathrm{Cu}$, whole-body retention of ${ }^{64} \mathrm{Cu}$ and specific activity of ${ }^{64} \mathrm{Cu}$ in the liver were increased in rats fed on ascorbate (Van den Berg et al. 1990). This effect may relate to the reduced tissue $\mathrm{Cu}$ concentrations in rats fed on ascorbate, because in nutritionally $\mathrm{Cu}$-deficient rats whole-body retention of intraperitoneally administered ${ }^{64} \mathrm{Cu}$ was also increased (Van den Berg et al. 1990, 1991). Further evidence supporting this concept comes from the observation that liver cells isolated from $\mathrm{Cu}$-deficient rats have increased efficiency of $\mathrm{Cu}$ uptake (Van den Berg et al. 1991). Thus, dietary ascorbic acid may have indirect effects, i.e. effects caused by ascorbate-induced decreased tissue $\mathrm{Cu}$ concentrations.

With the use of a human erythroleukemic cell line (K562 cells) it was shown that ascorbate enhances $\mathrm{Cu}$ transport from ceruloplasmin into the cells (Percival \& Harris, 1989). DiSilvestro \& Harris (1981) have shown an enhancing effect of ascorbate, when administered together with $\mathrm{Cu}$, on lysyl oxidase (EC 1.4.3.13) activity in chick aorta, a $\mathrm{Cu}$-dependent enzyme extremely sensitive to changes in dietary $\mathrm{Cu}$. These studies point to a direct effect of ascorbate. It may be caused by enhancement of $\mathrm{Cu}$ dissociation by reduction of $\mathrm{Cu}(\mathrm{II})$ to $\mathrm{Cu}(\mathrm{I})$, which promotes the availability of $\mathrm{Cu}$ for cellular uptake (Van den Berg \& Van den Hamer, 1984; Ettinger et al. 1986). Thus, the indirect and direct effects of ascorbate on cellular $\mathrm{Cu}$ uptake are complementary.

To unravel further the metabolic basis for the reduced tissue $\mathrm{Cu}$ concentrations after ascorbic acid feeding, the influence of ascorbate on hepatic uptake and biliary excretion of $\mathrm{Cu}$ is of interest. Bile is the main route by which $\mathrm{Cu}$ leaves the body and, thus, biliary $\mathrm{Cu}$ excretion plays an important role in $\mathrm{Cu}$ homeostasis. We have carried out in vitro and in vivo experiments to study the effect of ascorbate on hepatic $\mathrm{Cu}$ metabolism. The previously-mentioned studies with rats (Van Campen \& Gross, 1968; Johnson \& Murphy, 1988; Van den Berg et al. 1990) have employed diets containing $10 \mathrm{~g}$ ascorbic acid $/ \mathrm{kg}$, which is equivalent to intakes of about $1 \mathrm{~g}$ ascorbic acid $/ \mathrm{kg}$ body-weight. Compared with common doses of ascorbic acid supplementation in humans (Finley \& Cerklewski, 1983; Jacob et al. 1987) such intakes are unrealistically high, which might interfere with extrapolation of the rat findings to man. Therefore, we have studied not only the effects on $\mathrm{Cu}$ metabolism in rats of diets containing $10 \mathrm{~g}$ ascorbic acid $/ \mathrm{kg}$, but also those of diets containing $1 \mathrm{~g}$ ascorbic acid $/ \mathrm{kg}$. The effects of $1 \mathrm{~g}$ ascorbic acid $/ \mathrm{kg}$ were studied using diets containing either recommended (National Research Council, 1978) or low amounts of $\mathrm{Cu}$ because in animals fed on a low- $\mathrm{Cu}$ diet the effects of ascorbic acid feeding may be more pronounced.

\section{MATERIALS AND METHODS}

\section{Expt 1. Cu uptake by isolated rat hepatocytes}

Male Wistar rats of the HSD/Cpb:WU strain (Harlan-CPB, Zeist) were used as hepatocyte donors. The rats were aged 10 weeks and had been fed on a commercial pelleted diet (SRMA ${ }^{\text {; }}$; Hope Farms, Woerden) and tap water ad lib. Hepatocytes were isolated by the collagenase (EC 3.4.24.3) perfusion method of Berry \& Friend (1969). Primary parenchymal cell cultures were obtained by selective attachment to collagenized plastic dishes (diameter, $60 \mathrm{~mm}$ ) for $2 \mathrm{~h}$ at $37^{\circ}$ in a Ham's F-10 medium (Ham, 1963) supplemented with fetal calf serum $(120 \mathrm{ml} / \mathrm{l})$. Various concentrations of ascorbate (L-ascorbate; Merck, Darmstadt, Germany) and ${ }^{64} \mathrm{Cu}$ acetate $(15 \mu \mathrm{mol} \mathrm{Cu} / 1)$ were added to the medium. After various incubation periods at $37^{\circ}$ the radioactive medium was aspirated and the cells were 
harvested and washed twice with Ham's F-10 before measurement of cellular ${ }^{64} \mathrm{Cu}$. Net $\mathrm{Cu}$ uptake by hepatocytes was expressed as $\mathrm{ng} \mathrm{Cu} / \mathrm{mg}$ cellular protein, and was corrected for non-specific $\mathrm{Cu}$ binding or uptake, or both, by subtracting cellular radioactivity determined after incubation of hepatocytes at $4^{\circ}$ in parallel experiments. To test whether ascorbate interacts specifically with $\mathrm{Cu}$ uptake, ${ }^{65} \mathrm{ZnCl}_{2}$ uptake by hepatocytes was also measured. For this purpose, ${ }^{65} \mathrm{ZnCl}_{2}\left(12 \mu \mathrm{mol} \mathrm{Zn} / 1\right.$; specific activity $35 \mathrm{TBq}{ }^{65} \mathrm{Zn} / \mathrm{g} \mathrm{Zn}$; Radiochemical Centre, Amersham, UK) was added to the medium of parallel incubations.

\section{Expt 2. Hepatic uptake and biliary excretion of ${ }^{64} \mathrm{Cu}$ after intravenous administration of ${ }^{64} \mathrm{Cu}$ with or without ascorbate}

Male Wistar rats, aged 10 weeks and weighing on average $250 \mathrm{~g}$, were used. The rats had been fed on commercial pelleted diet and tap water $a d$ lib. The animals were anaesthetized with pentobarbital sodium $\left(60 \mathrm{mg} / \mathrm{kg}\right.$ body-weight intraperitoneally; Nembutal ${ }^{\circledR}$, Sanofi Sante Animale SA, Paris, France). The bile duct was cannulated as described elsewhere (Villalon et al. 1987). Body temperature was kept at $37^{\circ}$ with the use of a thermostaticallycontrolled heating lamp. At 15 min after collection of the first bile, ${ }^{64} \mathrm{Cu}$ acetate $(0.5 \mu \mathrm{g} \mathrm{Cu})$ with or without $0.1 \mathrm{mg}$ ascorbate in phosphate-buffered saline $(9 \mathrm{~g}$ sodium chloride/l) was injected intravenously; a total volume of $0.25 \mathrm{ml}$ was injected per animal. Bile was then collected for a period of $150 \mathrm{~min}$ after which the rats were killed by exposure to carbon dioxide. Blood was collected by aortic puncture and livers were removed. ${ }^{64} \mathrm{Cu}$ was measured in bile, liver and carcass without liver.

\section{Expt 3. Effect of a diet containing $10 \mathrm{~g}$ ascorbic acid/ $\mathrm{kg}$ on $\mathrm{Cu}$ metabolism}

Male, specified-pathogen-free Wistar rats, aged about 3 weeks, were used. On arrival in the animal house they were kept, three animals in a cage, in wire-topped Makrolon-3 cages (UNO BV, Zevenaar) with a layer of sawdust as bedding. For $10 \mathrm{~d}$ they were fed ad lib. on a purified diet containing $5 \mathrm{mg} \mathrm{Cu} / \mathrm{kg}$. The diet was formulated according to the recommended nutrient requirements of rats (National Research Council, 1978); its composition is given in Table 1 . After the pre-experimental period of $10 \mathrm{~d}$ (day 0 ) the rats were divided into two groups consisting of six rats each. One group remained on the preexperimental diet and the other group was transferred to the diet containing $10 \mathrm{~g}$ ascorbic acid/kg (Table 1).

On day 28 the animals received a single oral dose of ${ }^{64} \mathrm{Cu}$ acetate $(5 \mu \mathrm{g} \mathrm{Cu})$ and on day 35 an intraperitoneal injection of ${ }^{64} \mathrm{Cu}$ acetate $(5 \mu \mathrm{g} \mathrm{Cu})$ in $0.25 \mathrm{ml}$ sodium acetate buffer $\left(0.05 \mathrm{~mol} / \mathrm{l}, \mathrm{pH} \mathrm{5.4)}\right.$. After the administration of ${ }^{64} \mathrm{Cu}$, urine and faeces were collected during $3 \mathrm{~d}$ for determination of ${ }^{64} \mathrm{Cu}$, and ${ }^{64} \mathrm{Cu}$ whole-body measurements were extended over $96 \mathrm{~h}$. True efficiency of $\mathrm{Cu}$ absorption was calculated according to Heth \& Hoekstra (1965).

On day 42 , the bile duct was cannulated while under pentobarbital anaesthesia. After another $15 \mathrm{~min},{ }^{61} \mathrm{Cu}$ acetate $(0.5 \mu \mathrm{g} \mathrm{Cu})$ was administered intravenously. Subsequently, bile was collected over a total period of $150 \mathrm{~min}$. Then the rats were killed by exposure to $\mathrm{CO}_{2}$ and livers excised. ${ }^{64} \mathrm{Cu}$ in whole liver, body (minus liver) and total bile was measured and expressed as a percentage of the administered dose. Liver metallothionein, $\mathrm{Cu}$ in selected tissues, plasma ascorbate, packed cell volume, blood haemoglobin and plasma ceruloplasmin (as its oxidase activity) were determined.

\section{Expt 4. Effects of diets containing $1 \mathrm{~g}$ ascorbic acid/ $\mathrm{kg}$ on $\mathrm{Cu}$ metabolism}

Male Wistar rats aged about 3 weeks were used. All animals were fed on the purified diet containing $5 \mathrm{mg} \mathrm{Cu} / \mathrm{kg}$. After $10 \mathrm{~d}$, on day 0 of the experimental period, the rats were divided into four groups of equal size so that group mean body-weights were similar. Each 
Table 1. Expts 3 and 4. Composition of the purified diets used

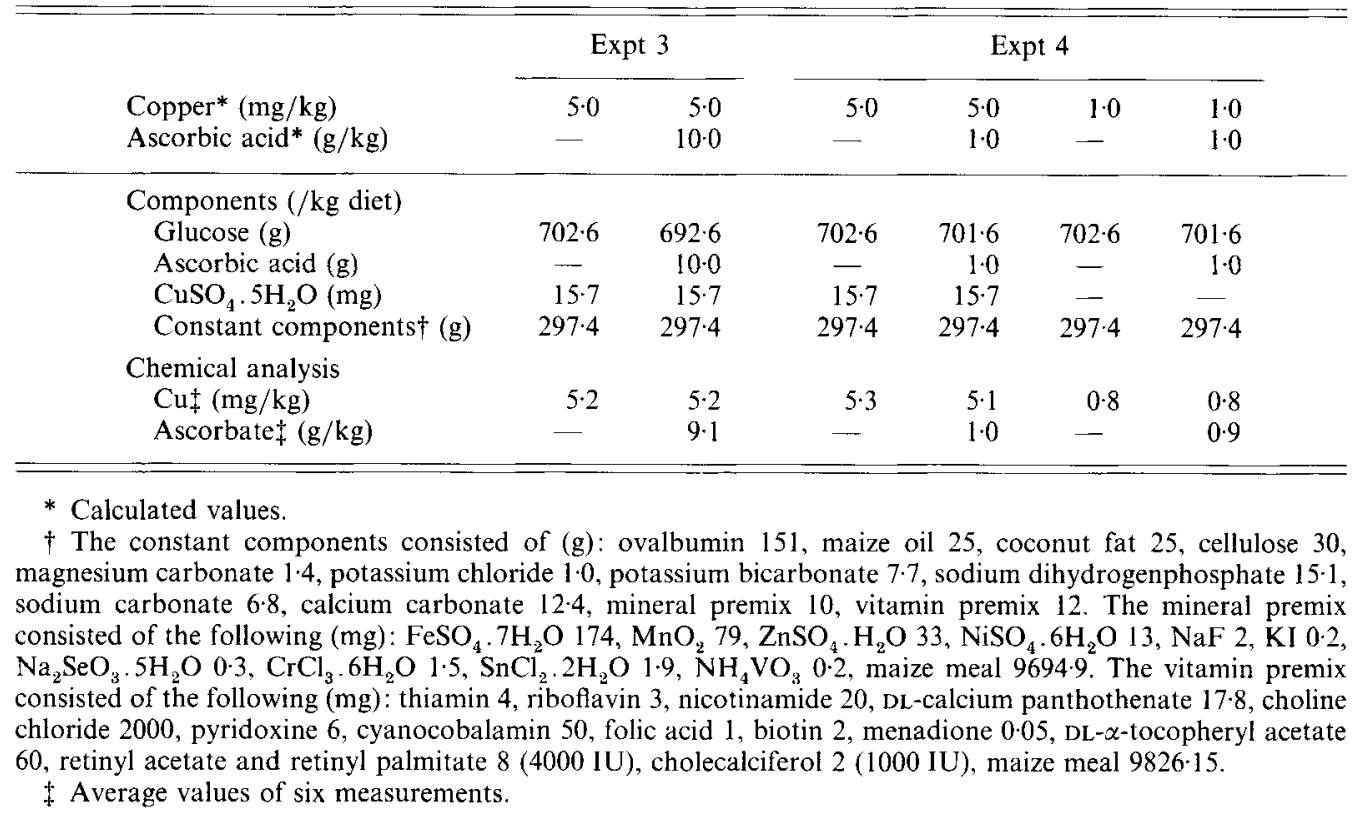

group was randomly assigned to one of four experimental diets. The diets contained $5 \mathrm{mg}$ $\mathrm{Cu} / \mathrm{kg}$ with or without $1 \mathrm{~g}$ ascorbic acid/ $\mathrm{kg}$ or $1 \mathrm{mg} \mathrm{Cu} / \mathrm{kg}$ with or without $1 \mathrm{~g}$ ascorbic $\mathrm{acid} / \mathrm{kg}$. The former diet was identical to the pre-experimental diet.

The composition of the diets is given in Table 1 . The experiment was carried out with three cohorts of twelve rats each, that is three rats per dietary group. The interval between the experiment with the first and second cohort was 1 week, and that between the second and third cohort was 16 weeks. During the experimental period (days 0-28) the rats were housed individually in metabolism cages (Techniplast Gazzada, Buguggiate, Italy). One batch of diet was used for the three cohorts. The diets, which were in powdered form, were stored at $-20^{\circ}$ until feeding. The concentration of ascorbic acid was checked before the study of each cohort.

From days 11 to 13 and days 24 to 26 urine and faeces of each rat were collected quantitatively. The tubes for collecting faeces and urine had been cleaned with $0 \cdot 1 \mathrm{~mol}$ hydrochloric acid/l. Urinary and faecal $\mathrm{Cu}$ were analysed.

On day 24 each non-starved rat was injected intraperitoneally with ${ }^{64} \mathrm{Cu}$ acetate $(25 \mu \mathrm{g}$ $\mathrm{Cu} / \mathrm{kg}$ body-weight) and ${ }^{64} \mathrm{Cu}$ whole-body retention was determined. Urine and faeces were collected during $3 \mathrm{~d}$ for determination of ${ }^{64} \mathrm{Cu}$.

On day 28 the animals were killed by exposure to $\mathrm{CO}_{2}$. Blood samples were taken by aortic puncture. Tissues were collected, weighed, and frozen at $-20^{\circ}$ until analysis. Plasma ascorbate, packed cell volume, blood haemoglobin and plasma ceruloplasmin were determined.

\section{${ }^{64} \mathrm{Cu}$ and radiochemical analyses}

${ }^{64} \mathrm{Cu}$ was obtained by irradiating a $\mathrm{Cu}$ wire (purity $99.999 \%$; Ventron, Karlsruhe, Germany) in a thermal neutron flux of $10^{17} / \mathrm{m}^{2}$ per $\mathrm{s}$ for $36 \mathrm{~h}$ in the reactor of the Interfaculty Reactor Institute of the Delft University of Technology. Following irradiation, the wire was dissolved in $25 \mu \mathrm{l}$ nitric acid (undiluted) and diluted with sodium acetate 
Table 2. Expt 1. Effect of ascorbate on copper uptake by isolated hepatocytes from rats*

(Values are means for triplicate determinations; the pooled SE was $2 \cdot 3$. Results for one cell preparation are shown: similar results were found with other preparations $(n 3))$

\begin{tabular}{ccccc}
\hline \hline & \multicolumn{3}{c}{$\begin{array}{c}\text { Cu uptake } \\
\text { (ng Cu/mg cellular protein) }\end{array}$} \\
\cline { 2 - 6 } $\begin{array}{c}\text { Ascorbate in incubation medium } \\
(\mu \mathrm{mol} / 1) \ldots \\
\text { Incubation period (min) }\end{array}$ & 0 & 10 & 100 & 1000 \\
30 & 16 & 28 & 33 & 50 \\
60 & 29 & 38 & 48 & 76 \\
120 & 59 & 66 & 76 & 136 \\
\hline
\end{tabular}

* For details of procedures, see pp. 702-703.

There were significant effects of ascorbate, incubation period and interaction (two-way analysis of variance; $P<0.001)$.

buffer $(0.05 \mathrm{~mol} / \mathrm{l}, \mathrm{pH} 5.4)$ resulting in a final $\mathrm{Cu}$ concentration of $1 \mathrm{mg} / \mathrm{ml}$. The specific activity of the ${ }^{64} \mathrm{Cu}$ solution at the start of the experiments was $320 \mathrm{GBq}{ }^{64} \mathrm{Cu} / \mathrm{g} \mathrm{Cu}$ $(8.5 \mathrm{Ci} / \mathrm{g})$.

${ }^{64} \mathrm{Cu}$ in urine, faeces, bile and tissues was determined by gamma counting (Philips Model PW4800 with a $3 \times 3$ inch sodium iodide crystal detector; overall efficiency of $6 \%$ ).

${ }^{64} \mathrm{Cu}$ whole-body retention was determined with a whole-body counter specially designed for rats (Van Barneveld \& Van den Hamer, 1985). The overall efficiency of this counter for ${ }^{64} \mathrm{Cu}$ was $14 \%$. Whole-body counting of the animals was performed within $2 \mathrm{~h}$ postinjection and at regular intervals for another $96 \mathrm{~h}$.

\section{Chemical analyses}

Urine and faeces were pretreated for $\mathrm{Cu}$ analysis. Urine was acidified to $\mathrm{pH} 1$ with 6 mol $\mathrm{HCl} / \mathrm{l}$, and centrifuged for $10 \mathrm{~min}$. The supernatant fraction was used for $\mathrm{Cu}$ analysis. Faeces were freeze-dried, ashed at $500^{\circ}$ for $18 \mathrm{~h}$ and dissolved in $6 \mathrm{~mol} \mathrm{HCl} / 1$. Tissues were freeze-dried and then digested with $\mathrm{HNO}_{3}$ (Suprapur; Merck, Darmstadt, Germany) and hydrogen peroxide (Aristar; BDH Chemicals, Poole, UK). The mixture consisted of $1 \mathrm{~g}$ tissue $/ 1 \mathrm{HNO}_{3}-\mathrm{H}_{2} \mathrm{O}_{2}(13: 6, \mathrm{v} / \mathrm{v})$. Feed samples were pretreated for $\mathrm{Cu}$ analysis as described for faeces. All $\mathrm{Cu}$ analyses were performed by flame atomic absorption spectrometry with the use of a Varian AA-475 (Varian Technotron, Springvale, Australia). The accuracy was evaluated by concurrent analysis of Standard Reference Material 1577 Bovine Liver (US National Institute of Standards and Technology, Gaithersburg, Maryland, USA). We found 156 (SE 3) $\mu \mathrm{g} \mathrm{Cu} / \mathrm{g}$ (n 6 runs), while the certified value was $158 \mu \mathrm{g} \mathrm{Cu} / \mathrm{g}$.

Ascorbic acid in diet samples was quantified after extraction with 0.68 mol metaphosphoric acid/1 by high-performance liquid chromatography (HPLC) with electrochemical detection (Yoshiura \& Iriyama, 1986). For the analysis of plasma ascorbate, plasma was mixed with $0.54 \mathrm{~mol}$ metaphosphoric acid/1 $(1: 4, \mathrm{v} / \mathrm{v})$ in order to precipitate proteins and to stabilize ascorbate (Parviainen et al. 1986). Ascorbate was then determined by a HPLC method applying pre-column derivatization and spectrofluorometry (Speek et al. 1984).

Ceruloplasmin in plasma was measured by its enzymic oxidase activity, using $p$-phenylenediamine as substrate. The $p$-phenylenediamine oxidase activity of rat ceruloplasmin was converted to a concentration of ceruloplasmin $(\mathrm{g} / \mathrm{l})$ as described by 
Table 3. Expt 2. ${ }^{64} \mathrm{Cu}$ distribution (\% dose) in tissues and bile $150 \mathrm{~min}$ after intravenous administration of ${ }^{64} \mathrm{Cu}(0.5 \mu \mathrm{g} \quad \mathrm{Cu} / \mathrm{rat})$ in the absence or presence of ascorbate $(0 \cdot 1 \mathrm{mg} / \mathrm{rat}) \dagger$

(Mean values with their standard errors for three rats per group)

\begin{tabular}{|c|c|c|c|c|}
\hline \multirow{2}{*}{$\begin{array}{l}\text { Intravenous supplement... } \\
\text { Site of }{ }^{64} \mathrm{Cu}\end{array}$} & \multicolumn{2}{|c|}{ None } & \multicolumn{2}{|c|}{ Ascorbate } \\
\hline & Mean & $\mathbf{S E}$ & Mean & $\mathrm{SE}$ \\
\hline Liver & 42 & 1.7 & $53^{*}$ & $4 \cdot 6$ \\
\hline Bile & 11 & $1 \cdot 2$ & $16^{*}$ & $1 \cdot 7$ \\
\hline Carcass & 43 & $2 \cdot 9$ & $25^{*}$ & $2 \cdot 2$ \\
\hline
\end{tabular}

Mean values were significantly different from those of animals not given ascorbate (two-tailed Student's $t$ test): * $P<0.05$.

$\dagger$ For details of procedures, see p. 703.

Sunderman \& Nomoto (1970). Blood haemoglobin was measured spectrophotometrically as metcyanohaemoglobin at $540 \mathrm{~nm}$ using Lyse S (Coulter Electronics, Krefeld, Germany). Liver metallothionein was determined by the 'Cd-hem' method reported by Onosaka \& Cherian (1981).

\section{Statistical analysis}

The Kolmorgorov-Smirnov one-sample test was used to check normality of the data. For data distributed normally either Student's $t$ test, one-way or two-way analysis of variance was applied to disclose statistically significant effects of treatments as indicated in the tables. Data not distributed normally were transformed logarithmically and then checked for homogeneity of variances (Cochran's C test); subsequently, statistically significant differences were evaluated as indicated previously for normally distributed data.

\section{RESULTS}

\section{Expt 1. Cu uptake by isolated hepatocytes}

Hepatocytes accumulated ${ }^{64} \mathrm{Cu}$ (Table 2) with time and this was a temperature-dependent process because at $4^{\circ} \mathrm{Cu}$ uptake rates were less than $5 \%$ of those measured at $37^{\circ}$ (values not shown). When ascorbate was added to the incubation medium a marked increase in ${ }^{64} \mathrm{Cu}$ uptake occurred which depended on the ascorbate concentration (Table 2). On the other hand, the addition of ascorbate to the incubation medium $(1000 \mu \mathrm{mol} / \mathrm{l})$ stimulated uptake of ${ }^{65} \mathrm{Zn}$ by hepatocytes on average by $12 \%$, but this effect did not reach statistical significance.

Expt 2. Hepatic uptake and biliary excretion of ${ }^{64} \mathrm{Cu}$ after intravenous administration of ${ }^{64} \mathrm{Cu}$ without or with ascorbate

Table 3 shows that rats injected with ascorbate accumulated more ${ }^{64} \mathrm{Cu}$ in liver and excreted more in bile, whereas their remaining carcass contained less ${ }^{64} \mathrm{Cu}$ compared with controls.

Expt 3. Effect of a diet containing $10 \mathrm{~g}$ ascorbic acid $/ \mathrm{kg}$ on $\mathrm{Cu}$ metabolism The addition of ascorbic acid to the diet at a concentration of $10 \mathrm{~g} / \mathrm{kg}$ caused a more than twofold increase in plasma ascorbate levels (Table 4). Ascorbate did not influence bodyweight gain. Packed cell volume and blood haemoglobin concentrations were significantly reduced by ascorbate intake. Rats fed on ascorbic acid showed significantly decreased 
Table 4. Expt 3. Effect of feeding a diet containing $10 \mathrm{~g}$ ascorbic acid/ $\mathrm{kg}$ for 6 weeks on body-weight, haematological variables and tissue copper concentrations of rats $\dagger$

(Mean values with their standard errors for six rats per group)

\begin{tabular}{|c|c|c|c|c|}
\hline \multirow[t]{2}{*}{ Dietary ascorbic acid $(\mathrm{g} / \mathrm{kg}) \ldots$} & \multicolumn{2}{|c|}{ None } & \multicolumn{2}{|c|}{10} \\
\hline & Mean & $\mathrm{SE}$ & Mean & $\mathrm{SE}$ \\
\hline \multicolumn{5}{|l|}{ Body-wt (g) } \\
\hline Initial & 80 & 0.8 & 79 & $1 \cdot 2$ \\
\hline Final & 249 & $7 \cdot 8$ & 248 & $5 \cdot 7$ \\
\hline \multicolumn{5}{|l|}{ Plasma } \\
\hline Ascorbate $(\mu \mathrm{mol} / 1)$ & 100 & 13.9 & $254^{* * *}$ & $22 \cdot 0$ \\
\hline $\begin{array}{l}\text { Ceruloplasmin } \neq \\
(E C 1.16 .3 .1)(\mathrm{g} / \mathrm{l})\end{array}$ & $0 \cdot 67$ & 0.05 & $0.54^{*}$ & $0-03$ \\
\hline Packed cell volume & 0.483 & 0.012 & $0.430^{* *}$ & 0.004 \\
\hline Haemoglobin $(\mathrm{mmol} / \mathrm{l})$ & $9 \cdot 1$ & 0.2 & $6 \cdot 5^{* *}$ & 0.5 \\
\hline \multicolumn{5}{|l|}{$\mathrm{Cu}$ concentrations $\$(\mu \mathrm{g} / \mathrm{g})$} \\
\hline Plasma $(u \mathrm{~g} / \mathrm{ml})$ & $1 \cdot 16$ & 0.06 & $0.85^{* *}$ & 0.05 \\
\hline Liver & $12 \cdot 33$ & 0.71 & $9 \cdot 39^{*}$ & 0.74 \\
\hline Kidney & $19 \cdot 27$ & 0.78 & $17 \cdot 20^{*}$ & 0.49 \\
\hline Heart & $24 \cdot 67$ & $0 \cdot 33$ & $22 \cdot 30^{*}$ & 0.93 \\
\hline Spleen & $5 \cdot 30$ & $0 \cdot 36$ & $4 \cdot 11^{*}$ & 0.29 \\
\hline Muscle & 3.97 & $0 \cdot 19$ & $3 \cdot 32^{*}$ & $0 \cdot 12$ \\
\hline Bone & $2 \cdot 87$ & 0.06 & $2 \cdot 11^{* * *}$ & 0.07 \\
\hline Skin & 5.00 & 0.36 & $4 \cdot 10$ & 0.21 \\
\hline $\begin{array}{l}\text { Metallothionein } \\
(\mu \mathrm{g} / \mathrm{g} \text { liver })\end{array}$ & 35 & $4 \cdot 1$ & 32 & $3 \cdot 7$ \\
\hline
\end{tabular}

Mean values were significantly different from those of animals not given ascorbic acid (two-tailed Student's $t$ test): ${ }^{*} P<0.05,{ }^{* *} P<0.01,{ }^{* * *} P<0.001$.

$\dagger$ For details of procedures, see p. 703.

As measured by its oxidase activity.

$\S$ As $\mu \mathrm{g} \mathrm{Cu} / \mathrm{g}$ dry weight.

activities of plasma ceruloplasmin. Control values of ceruloplasmin-protein concentration correspond well with those reported by other workers (DiSilvestro et al. 1988). Ascorbic acid feeding lowered $\mathrm{Cu}$ concentrations in plasma, liver, kidney, heart, spleen, muscle and bone. Group mean concentrations of $\mathrm{Cu}$ in skin were also lowered by ascorbic acid intake, but this effect just failed to reach statistical significance.

Whole-body retention of ${ }^{64} \mathrm{Cu}$ after oral and intraperitoneal administration of ${ }^{64} \mathrm{Cu}$ is shown in Fig. 1. Orally administered ${ }^{64} \mathrm{Cu}$ was not retained as efficiently as intraperitoneally injected ${ }^{64} \mathrm{Cu}$. Biological half-lives of orally and intraperitoneally administered ${ }^{64} \mathrm{Cu}$ were 4.7 (SE 0.3) d and $5 \cdot 2$ (SE 0.4) d ( $n$ 5) respectively for rats fed on the diet without ascorbic acid. The differences induced by ascorbic acid were not statistically significant. However, $\mathrm{Cu}$ retention, as indicated by whole-body ${ }^{64} \mathrm{Cu}$ levels, was systematically higher in rats fed on ascorbic acid (Fig. 1). Cu absorption, as calculated from the $y$ intercept values after extrapolation of the linear part of the retention curves $(42-96 \mathrm{~h})$ for orally administered $v$. injected ${ }^{64} \mathrm{Cu}$, was 62 (SE 2 ) \% for control rats and 59 (SE 2$) \%(n 5)$ for rats fed on ascorbic acid.

Ascorbic acid in the diet did not influence faecal and urinary excretion of orally administered ${ }^{64} \mathrm{Cu}$ (Table 5). The excretion of ${ }^{64} \mathrm{Cu}$ in the faeces after intraperitoneal administration of ${ }^{64} \mathrm{Cu}$ was significantly decreased in rats fed on ascorbic acid. After intravenous administration of ${ }^{64} \mathrm{Cu}$ the amount of ${ }^{64} \mathrm{Cu}$ in the liver was similar for rats fed 


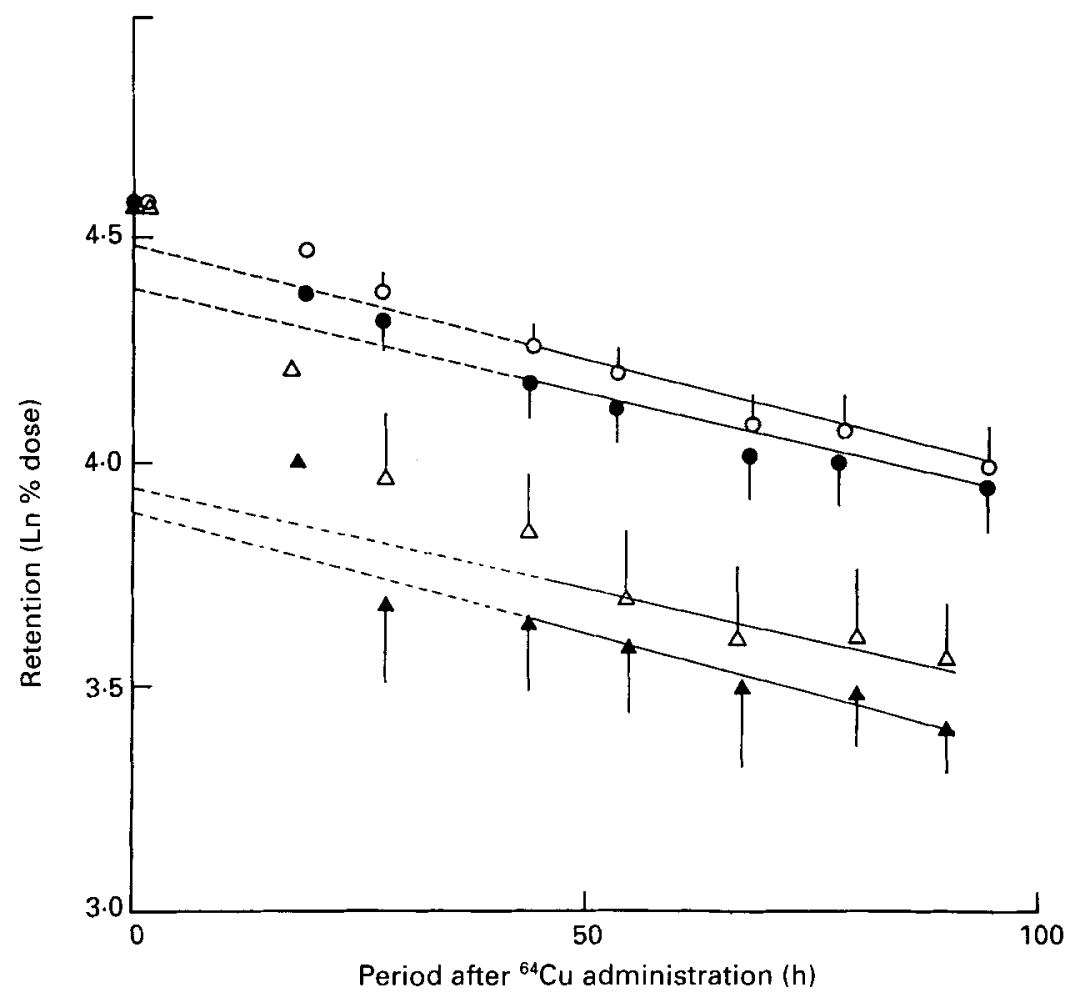

Fig. 1. Expt 3. Whole-body retention of orally $(\triangle, \mathbf{A})$ and intraperitoneally $(\mathrm{O}, \boldsymbol{O})$ administered ${ }^{64} \mathrm{Cu}$ in rats fed on diets with recommended $\mathrm{Cu}$ concentrations without $(\boldsymbol{A}, \boldsymbol{O})$ or with $(\triangle, O) 10 \mathrm{~g}$ ascorbic acid $/ \mathrm{kg}$. Results are means and standard deviations represented by vertical bars for five animals per dietary group. Linear fits were calculated over the time-period $42-96 \mathrm{~h}$ after ${ }^{64} \mathrm{Cu}$ administration. For details of procedures, see p. 703.

Table 5. Expt 3. Recovery of administered ${ }^{64} \mathrm{Cu}(\%$ dose $)$ in urine, faeces, liver and bile of rats fed on a diet containing $10 \mathrm{~g}$ ascorbic acid/ $\mathrm{kg} \dagger$

(Mean values with their standard errors for five rats per group)

\begin{tabular}{|c|c|c|c|c|c|}
\hline \multirow{2}{*}{$\begin{array}{l}\text { Dietary ascorbic acid }(\mathrm{g} / \mathrm{kg}) \ldots \\
\text { Route of }{ }^{64} \mathrm{Cu} \\
\text { administration } \neq\end{array}$} & \multirow{2}{*}{$\begin{array}{l}\text { Site of } \\
\text { recovery }\end{array}$} & \multicolumn{2}{|c|}{ None } & \multicolumn{2}{|c|}{10} \\
\hline & & Mean & SE & Mean & $\mathrm{SE}$ \\
\hline Oral & $\begin{array}{l}\text { Urine\$ } \\
\text { Faeces }\end{array}$ & $\begin{array}{r}3 \\
60\end{array}$ & $\begin{array}{l}0.5 \\
1 \cdot 2\end{array}$ & $\begin{array}{r}3 \\
59\end{array}$ & $\begin{array}{l}0.6 \\
3 \cdot 7\end{array}$ \\
\hline Intraperitoneal & $\begin{array}{l}\text { Urine§ } \\
\text { Facces } \$\end{array}$ & $\begin{array}{r}7 \\
34\end{array}$ & $\begin{array}{l}0 \cdot 7 \\
1.9\end{array}$ & $\begin{array}{c}5 \\
27^{*}\end{array}$ & $\begin{array}{l}0 \cdot 6 \\
2 \cdot 0\end{array}$ \\
\hline Intravenous & $\begin{array}{l}\text { Liver } \llbracket \\
\text { Bile } ₫ \\
\text { Carcass }\end{array}$ & $\begin{array}{l}43 \\
10 \\
40\end{array}$ & $\begin{array}{l}3 \cdot 1 \\
0 \cdot 9 \\
2 \cdot 7\end{array}$ & $\begin{array}{l}45 \\
13^{*} \\
35\end{array}$ & $\begin{array}{l}3 \cdot 0 \\
0 \cdot 9 \\
1 \cdot 8\end{array}$ \\
\hline
\end{tabular}

Mean values were significantly different from those of animals given the diet without ascorbic acid (two-tailed Student's $t$ test): ${ }^{*} P<0.05$.

$\dagger$ For details of procedures, see p. 703

${ }^{64} \mathrm{Cu}$ was administered after feeding the diets for the following periods (weeks): oral administration 4 , intraperitoneal administration 5, intravenous administration 6.

$\S^{64} \mathrm{Cu}$ accumulated for $3 \mathrm{~d}$ after administration.

. ${ }^{64} \mathrm{Cu}$ accumulated for $150 \mathrm{~min}$ after administration. 
Table 6. Expt 4. Effect of feeding a diet containing $1 \mathrm{~g}$ ascorbic acid/ $\mathrm{kg}$ for 4 weeks on body-weight, haematological variables and tissue copper concentrations in rats*

(Mean values for nine rats per dietary group)

\begin{tabular}{|c|c|c|c|c|c|c|c|}
\hline \multirow[b]{2}{*}{$\begin{array}{l}\mathrm{Cu} \dagger(\mathrm{mg} / \mathrm{kg}) \ldots \\
\text { Ascorbic acid } \ldots(\mathrm{g} / \mathrm{kg}) \ldots\end{array}$} & \multirow[b]{2}{*}{$\frac{5 \cdot 0}{-}$} & \multirow[b]{2}{*}{$\begin{array}{l}5 \cdot 0 \\
1 \cdot 0\end{array}$} & \multirow[b]{2}{*}{$1 \cdot 0$} & \multirow[b]{2}{*}{$\begin{array}{l}1.0 \\
1.0\end{array}$} & \multirow[b]{2}{*}{$\begin{array}{l}\text { Pooled } \\
\text { SE }\end{array}$} & \multicolumn{2}{|c|}{$\begin{array}{c}\text { Statistical } \\
\text { significance } \\
\text { of effect of } \neq \text { : }\end{array}$} \\
\hline & & & & & & $\begin{array}{l}\text { Ascorbic } \\
\text { acid }\end{array}$ & $\mathrm{Cu}$ \\
\hline \multicolumn{8}{|l|}{ Body-wt (g) } \\
\hline $\begin{array}{l}\text { Initial } \\
\text { Final }\end{array}$ & $\begin{array}{r}79 \\
201\end{array}$ & $\begin{array}{r}79 \\
197\end{array}$ & $\begin{array}{r}80 \\
194\end{array}$ & $\begin{array}{r}81 \\
183\end{array}$ & $\begin{array}{l}0 \cdot 1 \\
1.1\end{array}$ & & $P<0.001$ \\
\hline Feed intake $(\mathrm{g} / \mathrm{d})$ & $14 \cdot 0$ & $14 \cdot 1$ & $14 \cdot 2$ & $14 \cdot 0$ & $0 \cdot 1$ & - & - \\
\hline \multicolumn{8}{|l|}{ Plasma } \\
\hline $\begin{array}{l}\text { Ascorbate }(\mu \mathrm{mol} / \mathrm{l}) \\
\text { Ceruloplasmin } \\
(E C \text { } 1.16 .3 .1)(\mathrm{g} / \mathrm{l})\end{array}$ & $\begin{array}{l}92 \\
0 \cdot 60\end{array}$ & $\begin{array}{l}163 \\
0.59\end{array}$ & $\begin{array}{l}96 \\
0 \cdot 04\end{array}$ & $\begin{array}{r}153 \\
0 \cdot 06\end{array}$ & $\begin{array}{l}11 \cdot 1 \\
1 \cdot 62\end{array}$ & $\begin{array}{l}P<0.01 \\
-\end{array}$ & $P<0.001$ \\
\hline $\begin{array}{l}\text { Packed cell volume } \\
\text { Haemoglobin }(\mathrm{mmol} / \mathrm{l})\end{array}$ & $\begin{array}{l}0.452 \\
8 \cdot 6\end{array}$ & $\begin{array}{l}0 \cdot 427 \\
8 \cdot 1\end{array}$ & $\begin{array}{l}0 \cdot 386 \\
6 \cdot 9\end{array}$ & $\begin{array}{l}0-354 \\
6 \cdot 1\end{array}$ & $\begin{array}{l}0 \cdot 010 \\
0 \cdot 9\end{array}$ & $\begin{array}{l}P<0.01 \\
P<0.001\end{array}$ & $\begin{array}{l}P<0.001 \\
P<0.001\end{array}$ \\
\hline \multicolumn{8}{|l|}{$\mathrm{Cu}$ concentrations $\S(\mu \mathrm{g} / \mathrm{g})$} \\
\hline Plasma $(\mu \mathrm{g} / \mathrm{ml})$ & $1 \cdot 09$ & 0.98 & $<0.1$ & $<0.1$ & $1 \cdot 10$ & - & $P<0.001$ \\
\hline Liver & $10 \cdot 33$ & $9 \cdot 22$ & 6.49 & $6-06$ & 1.90 & $P<0.05$ & $P<0.001$ \\
\hline Heart & $20 \cdot 44$ & $19 \cdot 19$ & $11 \cdot 76$ & $11 \cdot 64$ & 1.67 & - & $P<0.001$ \\
\hline Kidney & $17 \cdot 01$ & $15 \cdot 75$ & $8 \cdot 84$ & $8 \cdot 16$ & $3 \cdot 46$ & - & $P<0.001$ \\
\hline Spleen & $5 \cdot 29$ & $4 \cdot 47$ & $1 \cdot 50$ & $1 \cdot 48$ & $3 \cdot 88$ & - & $P<0.001$ \\
\hline Muscle & $4 \cdot 52$ & $4 \cdot 34$ & $1 \cdot 48$ & $1 \cdot 23$ & 1.44 & - & $P<0.001$ \\
\hline Bone & $2 \cdot 74$ & $2 \cdot 48$ & 2.05 & 1.63 & 3.73 & - & $P<0.001$ \\
\hline Skin & 3.65 & 3.07 & 0.90 & 0.71 & 4.94 & - & $P<0.001$ \\
\hline
\end{tabular}

* For details of procedures, see pp. 703-704.

$\dagger$ Calculated values.

$\ddagger$ Two-way analysis of variance; plasma and spleen $\mathrm{Cu}$ concentrations were subjected to ANOVA after log transformation of the data.

$\S \mathrm{As} \mu \mathrm{g} \mathrm{Cu} / \mathrm{g}$ dry weight.

on diets without or with ascorbic acid (Table 5). Biliary excretion of ${ }^{64} \mathrm{Cu}$ was significantly increased by ascorbic acid feeding.

\section{Expt 4. Effects of diets containing $1 \mathrm{~g}$ ascorbic acid $/ \mathrm{kg}$ on $\mathrm{Cu}$ metabolism}

The addition of ascorbic acid to the diet at a concentration of $1 \mathrm{~g} / \mathrm{kg}$ caused a significant increase in plasma ascorbate levels (Table 6). Ascorbic acid tended to lower body-weight when fed in combination with the diet low in copper. Feed intakes were not influenced significantly by ascorbic acid or copper concentration of the diet (Table 6). Ascorbic acid reduced packed cell volume values and blood haemoglobin concentrations both in rats given diets with recommended and those with low $\mathrm{Cu}$ concentrations, the effect being somewhat more pronounced in the latter. Plasma ceruloplasmin (activity) was not influenced by ascorbate, but almost completely suppressed by low $\mathrm{Cu}$ intake.

In rats fed on the diets with the recommended $\mathrm{Cu}$ concentration, high ascorbic acid intake induced decreased group mean $\mathrm{Cu}$ concentrations in plasma and liver. Likewise, group mean concentrations of $\mathrm{Cu}$ in other tissues were lowered by dietary ascorbic acid. Feeding the diets with the low $\mathrm{Cu}$ concentration resulted in markedly lowered $\mathrm{Cu}$ concentrations in all tissues. 
Table 7. Expt 4. Apparent absorption of copper by rats fed on diets containing $1 \mathrm{~g}$ ascorbic acid $/ \mathrm{kg}^{*}$

(Mean values for nine rats per dietary group)

\begin{tabular}{|c|c|c|c|c|c|c|c|}
\hline \multirow{3}{*}{$\begin{array}{l}\mathrm{Cu} \dagger(\mathrm{mg} / \mathrm{kg}) \ldots \\
\text { Ascorbic acid }{ }^{+}(\mathrm{g} / \mathrm{kg}) \ldots\end{array}$} & \multirow{3}{*}{$5 \cdot 0$} & \multirow{3}{*}{$\begin{array}{l}5 \cdot 0 \\
1 \cdot 0\end{array}$} & \multirow{3}{*}{$1 \cdot 0$} & \multirow{3}{*}{$\begin{array}{l}1 \cdot 0 \\
1 \cdot 0\end{array}$} & \multirow{3}{*}{$\begin{array}{c}\text { Pooled } \\
\text { SE }\end{array}$} & \multicolumn{2}{|c|}{$\begin{array}{c}\text { Statistical } \\
\text { significance } \\
\text { of effect oft: }\end{array}$} \\
\hline & & & & & & Ascorbic & \\
\hline & & & & & & acid & $\mathrm{Cu}$ \\
\hline $\mathrm{Cu}$ intake $(\mu \mathrm{g} / \mathrm{d})$ & 74 & 71 & 12 & 11 & $0 \cdot 3$ & - & - \\
\hline Faecal $\mathrm{Cu}(\mu \mathrm{g} / \mathrm{d})$ & 43 & 55 & 4 & 5 & $1 \cdot 9$ & $P<0.01$ & $P<0.001$ \\
\hline \multicolumn{8}{|l|}{ Apparent absorption§ } \\
\hline$\mu \mathrm{g} / \mathrm{d}$ & 31 & 16 & 8 & 7 & $0 \cdot 7$ & $P<0.01$ & $P<0.001$ \\
\hline$\%$ of intake & 42 & 23 & 70 & 59 & $2 \cdot 1$ & $P<0.01$ & $P<0.001$ \\
\hline
\end{tabular}

* Values for days 11-13 and days 24-26 of the experiment. For details of procedures, see pp. 703-704.

+ Calculated values.

\$ All data were subjected to ANOVA after log transformation.

$\S$ Apparent absorption is expressed in absolute (intake - faecal output) and relative terms ( $100 \times$ (intake - faecal output)/intake).

Table 8. Expt 4. Excretion of intraperitoneally administered ${ }^{64} \mathrm{Cu}$ in urine and faeces of rats fed on diets containing $1 \mathrm{~g}$ ascorbic acid $/ \mathrm{kg}^{*}$

(Mean values for nine rats per dietary group)

\begin{tabular}{|c|c|c|c|c|c|c|c|}
\hline \multirow[b]{2}{*}{$\begin{array}{l}\text { Cu† }(\mathrm{mg} / \mathrm{kg}) \ldots \\
\text { Ascorbic acid } \dagger(\mathrm{g} / \mathrm{kg}) \ldots\end{array}$} & \multicolumn{5}{|c|}{${ }^{64} \mathrm{Cu}$ recovery (\% dose) } & \multicolumn{2}{|c|}{$\begin{array}{c}\text { Statistical } \\
\text { significance } \\
\text { of effect of }\end{array}$} \\
\hline & $-5 \cdot 0$ & $\begin{array}{l}5 \cdot 0 \\
1 \cdot 0\end{array}$ & 10 & $\begin{array}{l}1 \cdot 0 \\
1 \cdot 0\end{array}$ & $\begin{array}{l}\text { Pooled } \\
\text { SE }\end{array}$ & $\begin{array}{l}\text { Ascorbic } \\
\text { acid }\end{array}$ & $\mathrm{Cu}$ \\
\hline Urine & 7 & 8 & 2 & 2 & 0.4 & - & $P<0.001$ \\
\hline Faeces & 21 & 30 & 6 & 7 & $1 \cdot 1$ & $P<0.01$ & $P<0.001$ \\
\hline
\end{tabular}

* Values for days 24-26 of the experiment. For details of procedures, see pp. 703-704.

+ Calculated values.

$\ddagger$ All data were subjected to ANOVA after log transformation.

Dietary ascorbic acid increased faecal loss of $\mathrm{Cu}$ both in rats fed on diets with recommended and those with low $\mathrm{Cu}$ concentrations (Table 7). $\mathrm{Cu}$ in urine was not detectable. The absolute and percentage apparent absorption values of $\mathrm{Cu}$ were significantly decreased by dietary ascorbic acid. Low intake of $\mathrm{Cu}$ increased the apparent efficiency of $\mathrm{Cu}$ absorption.

Ascorbic acid in the diet significantly increased faecal excretion of intraperitoneally administered ${ }^{64} \mathrm{Cu}$ in rats given the diet with the recommended $\mathrm{Cu}$ concentration, but did not influence urinary excretion of ${ }^{64} \mathrm{Cu}$ (Table 8). The excretion of ${ }^{64} \mathrm{Cu}$ in faeces and urine was significantly decreased in rats fed on the low-Cu diet; dietary ascorbic acid did not affect ${ }^{64} \mathrm{Cu}$ excretion in these rats.

Whole-body retention of intraperitoneally administered ${ }^{64} \mathrm{Cu}$ is shown in Fig. 2. A significantly higher retention was found in rats fed on the low-Cu diets compared with rats fed on diets with the recommended $\mathrm{Cu}$ concentration. Biological half-lives of the 


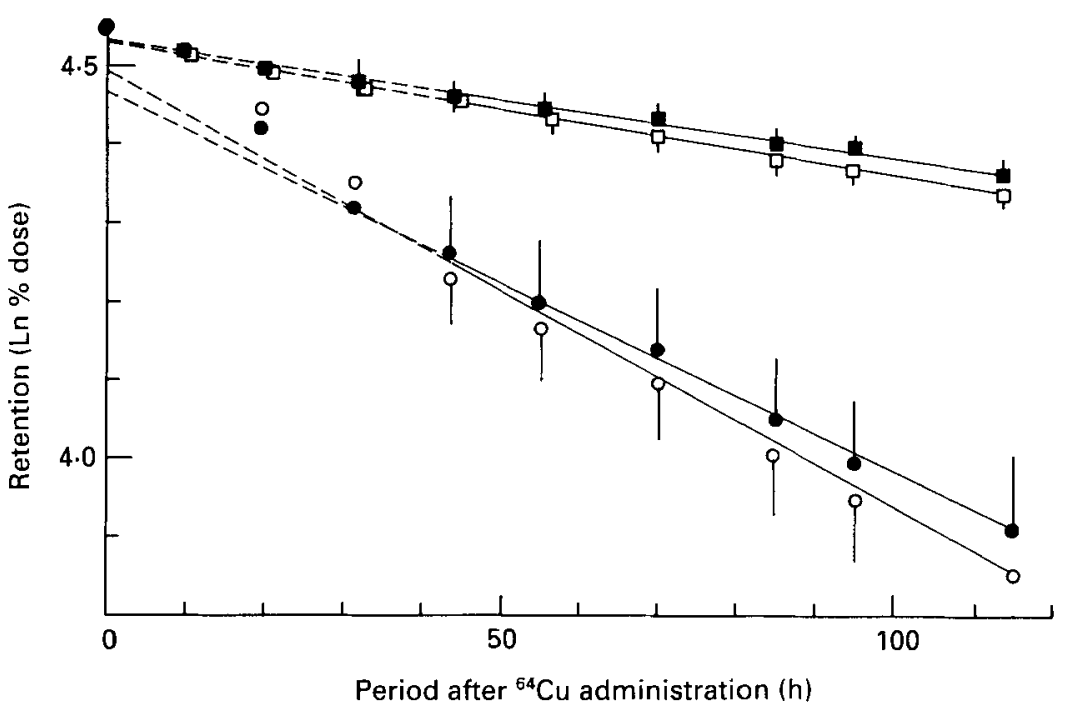

Fig. 2. Expt 4. Whole-body retention of intraperitoneally administered ${ }^{64} \mathrm{Cu}$ in rats fed on diets containing either recommended $(O, \odot)$ or low $(\square, \square)$ amounts of $\mathrm{Cu}$ without $(\boldsymbol{O}, \square)$ or with $(O, \square) 1 \mathrm{~g}$ ascorbic acid $/ \mathrm{kg}$. Results are means and standard deviations represented by vertical bars for nine animals per dietary group. Linear fits were calculated over the time-period $42-96 \mathrm{~h}$ after ${ }^{64} \mathrm{Cu}$ administration. For details of procedures, see pp. 703-704.

administered ${ }^{64} \mathrm{Cu}$ were $6 \cdot 0(\mathrm{SE} 0 \cdot 3)$ and $19 \cdot 0(\mathrm{SE} 0 \cdot 7) \mathrm{d}(n 9)$ respectively for rats fed on the recommended and low- $\mathrm{Cu}$ diets without added ascorbic acid. For the rats fed on the diets containing ascorbic acid, these values were $5 \cdot 0$ (SE 0.3 ) and 20.0 (SE $0 \cdot 7$ ) d respectively. Thus, dietary ascorbic acid tended to diminish $\mathrm{Cu}$ retention in rats given the diet with recommended $\mathrm{Cu}$ concentration, but this effect was very small.

\section{DISCUSSION}

The rat as model

We have used the rat as a model to study the effects of ascorbic acid supplementation on $\mathrm{Cu}$ metabolism. It could be argued that the rat is not a suitable model because this animal species, unlike humans, can synthesize adequate amounts of this vitamin. The feeding of rats with diets enriched with ascorbic acid resulted in a significant increase in plasma ascorbate concentrations. These results indicate that in the rat ascorbate status can be modulated by ascorbic acid intake, which may imply that the rat is a suitable model to study the effects of ascorbic acid supplementation on $\mathrm{Cu}$ metabolism. This is further supported by the observation that ascorbic acid feeding reduces plasma Cu concentrations in both humans (Finley \& Cerklewski 1983; Jacob et al. 1987; Milne et al. 1988) and rats (Johnson \& Murphy, 1988; present study).

\section{Ascorbic acid and $C u$ status}

Addition of ascorbic acid to diets with recommended $\mathrm{Cu}$ concentrations resulted in depressed plasma ceruloplasmin activity and decreased $\mathrm{Cu}$ concentrations in plasma and various tissues, especially liver. This agrees with findings of other studies using diets containing ascorbic acid concentrations in the range of $10-50 \mathrm{~g} / \mathrm{kg}$ (Van Campen \& Gross, 1968; Smith \& Bidlack, 1980; Johnson \& Murphy, 1988; Van den Berg et al. 1990). The present study shows that the feeding of a diet with $5 \mathrm{mg} \mathrm{Cu} / \mathrm{kg}$ containing only $1 \mathrm{~g}$ ascorbic $\mathrm{acid} / \mathrm{kg}$ for $28 \mathrm{~d}$ produced essentially the same effects on tissue $\mathrm{Cu}$ concentrations as did 
supplying a diet with ten times as much ascorbic acid for $42 \mathrm{~d}$. Feeding the high ascorbic acid diet for the longer period only produced slightly greater decreases of $\mathrm{Cu}$ concentrations in plasma, liver and other tissues. Thus, tissue $\mathrm{Cu}$ concentrations are clearly affected by ascorbic acid intake at levels as low as $0.1 \mathrm{~g} / \mathrm{kg}$ body-weight.

Dietary ascorbic acid lowered blood haemoglobin concentrations and packed cell volume values (Tables 4 and 6). It could be suggested that these effects are caused by ascorbate-induced lowering of tissue $\mathrm{Cu}$ concentrations. Diets containing $1 \mathrm{mg} \mathrm{Cu} / \mathrm{kg}$ not only lowered $\mathrm{Cu}$ concentrations in tissues but also caused depressed haemoglobin and packed cell volume (Table 6). Anaemia in rats as induced by $\mathrm{Cu}$ deficiency has been reported (Johnson \& Murphy, 1988). There was no statistically significant interaction of ascorbic acid and $\mathrm{Cu}$ intake with regard to haemoglobin concentrations and packed cell volume, but the effect of high ascorbic acid intake tended to be somewhat more pronounced against a dietary background low in $\mathrm{Cu}$. Such a tendency was also seen concerning growth performance. Final body-weight was reduced only with the combination of high ascorbic acid and low $\mathrm{Cu}$ concentrations in the diet (Table 6).

\section{Cu absorption}

It has been suggested (Van Campen \& Gross, 1968; Johnson \& Murphy, 1988; Van den Berg et al. 1990) that dietary ascorbic acid lowers tissue $\mathrm{Cu}$ concentrations through interference with the absorption of $\mathrm{Cu}$ from intestine. Indeed, in the present study we also found that the apparent absorption of $\mathrm{Cu}$ was significantly decreased after feeding a diet supplemented with $1 \mathrm{~g}$ ascorbic acid $/ \mathrm{kg}$ (Table 7). This may be related to an interaction of ascorbate and $\mathrm{Cu}$ at the level of the intestinal lumen. Ascorbate depressed the intestinal absorption of ${ }^{64} \mathrm{Cu}$ when the two materials were administered by stomach tube (Van den Berg et al. 1990). Furthermore, ascorbate reduced the disappearance of ${ }^{64} \mathrm{Cu}$ from ligated duodenal segments (Van Campen \& Gross, 1968). If ascorbate depresses intestinal $\mathrm{Cu}$ absorption, then retention of orally administered ${ }^{64} \mathrm{Cu}$ should be diminished in rats fed on ascorbic acid. This has indeed been shown earlier (Van Campen \& Gross, 1968). However, we found higher whole-body levels of ${ }^{64} \mathrm{Cu}$ at each time-point after oral administration of ${ }^{64} \mathrm{Cu}$ in rats fed on ascorbic acid (Fig. 1), while ascorbic acid did not influence calculated true $\mathrm{Cu}$ absorption. This might be explained by ascorbate-induced decreased tissue $\mathrm{Cu}$ concentrations. Low $\mathrm{Cu}$ intake caused an increased apparent absorption of $\mathrm{Cu}$ and an enhanced ${ }^{64} \mathrm{Cu}$ retention after intraperitoneal injection of ${ }^{64} \mathrm{Cu}$ (Fig. 2). Thus, the reduced tissue $\mathrm{Cu}$ concentrations as induced by ascorbic acid feeding may have masked effects of ascorbate at the level of intestinal absorption. This would also explain the lack of effect of ascorbate feeding on the recovery of orally administered ${ }^{64} \mathrm{Cu}$ in faeces (Table 5).

\section{Hepatic uptake of $\mathrm{Cu}$}

Ascorbate, intravenously administered together with ${ }^{64} \mathrm{Cu}$, caused an increase of ${ }^{64} \mathrm{Cu}$ recovery in liver (Table 3). This effect of ascorbate was observed at a dose of $0.1 \mathrm{mg} / \mathrm{rat}$. This caused a maximum increase of plasma ascorbate by about $115 \mu \mathrm{mol} / \mathrm{l}$, assuming that the rats had about $5 \mathrm{ml}$ plasma. Within this concentration range ascorbate clearly increased $\mathrm{Cu}$ uptake by isolated hepatocytes (Table 2).

Ascorbic acid feeding may also stimulate hepatic $\mathrm{Cu}$ uptake because it caused an increase of plasma ascorbate concentrations by about $100 \mu \mathrm{mol} / 1$ (Tables 4 and 6). However, no effect on accumulation of ${ }^{64} \mathrm{Cu}$ in liver was observed in rats fed on ascorbic acid and given ${ }^{64} \mathrm{Cu}$ intravenously (Table 5). This could be related to the reduced tissue $\mathrm{Cu}$ concentrations of rats fed on ascorbic acid. Low $\mathrm{Cu}$ intake induces increased efficiency of $\mathrm{Cu}$ uptake by various tissues (Van den Berg et al. 1990) and increased whole-body retention of ${ }^{64} \mathrm{Cu}$ in such rats (Fig. 2). Thus, circulating ascorbate and decreased cellular $\mathrm{Cu}$ concentrations 
both trigger $\mathrm{Cu}$ uptake by cells. Any specific effect of ascorbate on the distribution of ${ }^{64} \mathrm{Cu}$ between liver and other tissues after intravenous administration of ${ }^{64} \mathrm{Cu}$ may be masked by reduced concentrations of $\mathrm{Cu}$ in extrahepatic tissues. Moreover, the effect of ascorbate on the cellular uptake of $\mathrm{Cu}$ may not be specific for liver. Ascorbate has also been shown to stimulate $\mathrm{Cu}$ transport from ceruloplasmin into a human erythroleukemic cell line (Percival \& Harris, 1989).

\section{Biliary excretion of $\mathrm{Cu}$}

Intravenously administered ascorbate stimulated ${ }^{64} \mathrm{Cu}$ accumulation in bile of rats with a bile duct cannula (Table 3 ). In rats fed on a diet containing $10 \mathrm{~g}$ ascorbic acid $/ \mathrm{kg}$, more intravenously administered ${ }^{64} \mathrm{Cu}$ was recovered in bile than in rats fed on no ascorbic acid (Table 5). In keeping with ascorbate-induced stimulation of biliary $\mathrm{Cu}$ excretion, $1 \mathrm{~g}$ ascorbic acid $/ \mathrm{kg}$ in a diet with recommended $\mathrm{Cu}$ concentration enhanced the recovery of intraperitoneally administered ${ }^{64} \mathrm{Cu}$ in faeces (Table 8). However, an opposite effect was seen in rats fed on a diet containing $10 \mathrm{~g}$ ascorbic acid $/ \mathrm{kg}$ (Table 5). This may be explained by the $\mathrm{Cu}$-retaining effect of reduced tissue $\mathrm{Cu}$ concentrations induced by ascorbate, an effect being more pronounced in rats fed on $10 \mathrm{~g}$ instead of $1 \mathrm{~g}$ ascorbic acid $/ \mathrm{kg}$ diet.

The ascorbate-induced stimulation of biliary ${ }^{64} \mathrm{Cu}$ excretion seen in Expt 3, and indirectly in Expt 4, probably reflects the increased hepatic uptake of ${ }^{64} \mathrm{Cu}$ and, thus, may be the result of an increased specific activity of $\mathrm{Cu}$ in liver pools. This is supported by the observation that in rats fed on ascorbic acid the specific activity of liver $\mathrm{Cu}$ was increased by about $30 \%$ (Tables 4 and 5), while the increase in biliary ${ }^{64} \mathrm{Cu}$ excretion was of the same order of magnitude. Furthermore, it is unlikely that ascorbate promotes biliary excretion of $\mathrm{Cu}$ mass because the combination of impaired intestinal absorption of $\mathrm{Cu}$ and increased biliary excretion of $\mathrm{Cu}$ would not allow for a new steady-state of body $\mathrm{Cu}$ to be reached. As a consequence the animals would soon be fully depleted. We speculate that biliary excretion of $\mathrm{Cu}$ mass is depressed in rats fed on ascorbic acid. In any event, the ascorbateinduced lowering of tissue $\mathrm{Cu}$ concentrations will by itself reduce biliary $\mathrm{Cu}$ excretion. This is supported by the observation that low $\mathrm{Cu}$ intakes diminish biliary $\mathrm{Cu}$ excretion (Owen \& Hazelrig, 1968). In retrospect, it is unfortunate that we did not analyse the amount of $\mathrm{Cu}$ in bile fluid samples.

\section{Whole-body retention of ${ }^{64} \mathrm{Cu}$}

There was a discrepancy in the results for whole-body retention of intraperitoneally injected ${ }^{64} \mathrm{Cu}$ in rats fed on recommended $\mathrm{Cu}$ diets containing either 10 or $1 \mathrm{~g}$ ascorbic acid $/ \mathrm{kg}$. In rats fed on a $10 \mathrm{~g}$ ascorbic acid $/ \mathrm{kg}$ diet, the whole-body retention of ${ }^{64} \mathrm{Cu}$ was slightly increased (Fig. 1), whereas in rats fed on a $1 \mathrm{~g}$ ascorbic acid $/ \mathrm{kg}$ diet it was slightly decreased (Fig. 2). This may relate to the somewhat different tissue $\mathrm{Cu}$ concentrations in rats fed on the two ascorbate diets. Retention of intraperitoneally injected ${ }^{64} \mathrm{Cu}$ essentially refers to ${ }^{64} \mathrm{Cu}$ accumulated by cells minus urinary excretion of ${ }^{64} \mathrm{Cu}$ and non-reabsorbed ${ }^{64} \mathrm{Cu}$ excreted in bile. As shown earlier (Van den Berg et al. 1990), and in the present study (Fig. 2), low $\mathrm{Cu}$ intake increases ${ }^{64} \mathrm{Cu}$ retention, probably by stimulating cellular uptake of $\mathrm{Cu}$ (Van den Berg et al. 1990, 1991). Ascorbate, on the other hand, tends to decrease ${ }^{64} \mathrm{Cu}$ retention through increased biliary excretion of ${ }^{64} \mathrm{Cu}$. Apparently, in rats fed on the diet containing $10 \mathrm{~g}$ ascorbic acid/ $\mathrm{kg}$ for $42 \mathrm{~d}$ (Fig. 1) the net effect of ascorbate-induced lowering of tissue $\mathrm{Cu}$ concentrations and increased biliary excretion results in enhanced ${ }^{64} \mathrm{Cu}$ retention. In other words, the effect of reduced tissue $\mathrm{Cu}$ concentrations overrules that of circulating ascorbate. The opposite may hold for $\mathrm{Cu}$ retention (Fig. 2) in rats fed on the recommended $\mathrm{Cu}$ diet containing $1 \mathrm{~g}$ ascorbic acid $/ \mathrm{kg}$. 


\section{Conclusions}

It has been shown that dietary ascorbic acid concentrations of 1 and $10 \mathrm{~g} / \mathrm{kg}$ reduce tissue $\mathrm{Cu}$ concentrations in rats. Ascorbate interfered with intestinal $\mathrm{Cu}$ absorption. Ascorbate also stimulated hepatic uptake of ${ }^{64} \mathrm{Cu}$. This may be responsible for the observed ascorbateinduced enhancement of biliary excretion of intravenously administered ${ }^{64} \mathrm{Cu}$, although this should not necessarily be associated with an increased biliary excretion of $\mathrm{Cu}$ mass. Evidence is presented that, when studying the mechanism underlying the lowering of tissue $\mathrm{Cu}$ concentrations by ascorbic acid feeding, the primary effects of ascorbate itself and the secondary effects of the ascorbate-induced reduced tissue $\mathrm{Cu}$ concentrations should be distinguished.

The authors thank Inez Lemmens for expert analytical help, Gerrit Van Tintelen for biotechnical assistance, Gert Meijer and Hein van Lith for statistical assistance and Professor J. J. M. de Goeij for critical review of the manuscript.

\section{REFERENCES}

Berry, M. N. \& Friend, D. S. (1969). A high-yield preparation of isolated rat parenchymal cells. Journal of Cell Biology 43, 506-520.

DiSilvestro, R. A., Barber, E. F., David, E. A. \& Cousins, R. J. (1988). An enzyme-linked immunoadsorbent assay for rat ceruloplasmin. Biological Trace Element Research 17, 1-9.

DiSilvestro, R. A. \& Harris, E. D. (1981). A postabsorption effect of L-ascorbic acid on copper metabolism in chicks. Journal of Nutrition 111, 1964-1968.

Ettinger, M. J., Darwish, H. M. \& Schmitt, R. C. (1986). Mechanism of copper transport from plasma to hepatocytes. Federation Proceedings 45, 2800-2804.

Finley, E. B. \& Cerklewski, F. L. (1983). Influence of ascorbic acid supplementation on copper status in young adult men. American Journal of Clinical Nutrition 37, 553-556.

Ham, R. G. (1963). An improved nutrient solution for diploid chinese hamster and human cellines. Experimental Cell Research 29, 515-526.

Heth, D. A. \& Hoekstra, W. G. (1965). I. A procedure to determine zinc-65 absorption and the antagonistic effect of calcium in a practical diet. Journal of Nutrition $85,367-374$.

Hunt, C. E., Carlton, W. W. \& Newberne, P. M. (1970). Interrelationships between copper deficiency and dietary ascorbic acid in the rabbit. British Journal of Nutrition 24, 61-69.

Jacob, R. A., Skala, J. H., Omaye, S. T. \& Turnlund, J. R. (1987). Effect of varying ascorbic acid intakes on copper absorption and ceruloplasmin levels of young men. Journal of Nutrition 117, 2109-2115.

Johnson, M. A. \& Murphy, C. L. (1988). Adverse effects of high dietary iron and ascorbic acid on copper status in copper-deficient and copper-adequate rats. American Journal of Clinical Nutrition 47, 96-101.

Milne, D. B., Klevay, L. M. \& Hunt, J. R. (1988). Effects of ascorbic acid supplements and a diet marginal in copper on indices of copper nutriture in women. Nutrition Research 8, 865-873.

Milne, D. B. \& Omaye, S. T. (1980). Effect of vitamin C on copper and iron metabolism in the guinea pig. International Journal for Vitamin and Nutrition Research 50, 301-308.

Milne, D. B., Omaye, S. T. \& Amos, W. H. (1981). Effect of ascorbic acid on copper and cholesterol in adult cynomolgus monkeys fed a diet marginal in copper. American Journal of Clinical Nutrition 34, 2389-2393.

National Research Council (1978). Nutrient requirements of domestic animals. Nutrient Requirements of Laboratory Animals no. 10, 3rd ed. Washington, DC: National Academy of Sciences.

Onosaka, S. \& Cherian, M. G. (1981). The induced synthesis of metallothionein in various tissues of the rat in response to metals. I. Effect of repeated injection of cadmium salts. Toxicology 22, 91-96.

Owen, C. A. \& Hazelrig, J. B. (1968). Copper deficiency and copper toxicity in the rat. American Journal of Physiology 215, 334-338.

Parviainen, M. T., Nyyssönen, K., Penttilä, I. M., Seppänen, K., Rauramaa, R., Salonen, J. T. S. \& Gref, C.-G. (1986). A method for routine assay of plasma ascorbic acid using high-performance liquid chromatography. Journal of Liquid Chromatography 9, 2185-2197.

Percival, S. S. \& Harris, E. D. (1989). Ascorbate enhances copper transport from ceruloplasmin into human K562 cells. Journal of Nutrition 119, 779-784.

Smith, C. H. \& Bidlack, W. R. (1980). Interrelationships of dietary ascorbic acid and iron on the tissue distribution of ascorbic acid, iron and copper in female guinea pigs. Journal of Nutrition 110, 1398-1408.

Speek, A. J., Schrijver, J. \& Schreurs, W. H. P. (1984). Fluorometric determination of total vitamin C in whole blood by high-performance liquid chromatography with pre-column derivatization. Journal of Chromatography 305, 53-60. 
Sunderman, F. W. \& Nomoto, S. Jr (1970). Measurement of human serum ceruloplasmin by its p-phenylenediamine oxidase activity. Clinical Chemistry 16, 903-910.

Van Barneveld, A. A. \& Van den Hamer, C. J. A. (1984). Intestinal passage of simultaneously administered ${ }^{64} \mathrm{Cu}$ and ${ }^{65} \mathrm{Zn}$ and the effect of feeding in mouse and rat. Nutrition Reports International 29, 173-182.

Van Campen, D. \& Gross, E. (1968). Influence of ascorbic acid on the absorption of copper by rats. Journal of Nutrition 95, 617-622.

Van den Berg, G. J., De Goeij, J. J. M., Bock, I., Gijbels, M. J. J., Brouwer, A., Lei, K. Y. \& Hendriks, H. F. J. (1991). Copper uptake and retention in liver parenchymal cells isolated from nutritionally copper-deficient rats. Journal of Nutrition 121, 1228-1235.

Van den Berg, G. J. \& Van den Hamer, C. J. A. (1984). Trace metal uptake by liver cells. I. Influence of albumin in the medium on the uptake of copper by hepatoma cells. Journal of Inorganic Biochemistry 22, 73-84.

Van den Berg, G. J., Van Wouwe, J. P. \& Beynen, A. C. (1990). Ascorbic acid supplementation and Cu status in rats. Biological Trace Element Research 23, 165-172.

Villalon, L, Tuchweber, B. \& Yousef, I. M. (1987). Effect of a low protein diet on bile flow and composition in rats. Journal of Nutrition 117, 678-683.

Yoshiura, M. \& Iriyama, K. (1986). Simultaneous determination of ascorbic acid and uric acids in body fluids by high-performance liquid chromatography with electrochemical detection. Journal of Liquid Chromatography 9 , $177-188$. 